\title{
Effectiveness of Contextualization in Science Instruction to Enhance Science Literacy in the Philippines: A Meta-Analysis
}

\author{
Marchee T. Picardal \\ College of Teacher Education, Cebu Normal University, Philippines \\ Joje Mar P. Sanchez \\ College of Teacher Education, Cebu Normal University, Philippines
}

\begin{abstract}
A call for students to have a deeper understanding, so that they can make sense of and apply their learning to authentic situations, has reverberated in science teaching in the Philippines. In response, educators, teachers, and policymakers have embraced contextualization as a constructivist approach to bridging the gap between concepts and real-life experiences. Considering the popularity of this approach, it is imperative to examine the overall effectiveness of contextualization in improving students' achievement at all educational levels and in all science domains, compared to the traditional setup. By using a set of inclusion selection criteria, 10 Philippine-based studies conducted from 2017 to 2020 qualified to be included in a meta-analysis. Seven of the studies focused on the secondary level and three on tertiary level. Studies were extracted from several meta-search engines, namely Google Scholar, Science Direct, ERIC, and JSTOR; the search was facilitated by Harzing's Publish and Perish software. Statistical results from these studies were analyzed using Meta-Essentials, version 1.4, to calculate the effect sizes, to conduct subgroup and moderator analyses, and to determine publication bias. Contextualization is an approach to teaching science that could have a positive effect on students' achievement. The variables educational level and science domain were found to have no influence on student achievement. Contextualized instruction used various techniques to maximize achievement of learning outcomes. A further systematic review, covering a wider scope, must be conducted to examine indicators that may influence the implementation of contextualization in the teaching and learning process.
\end{abstract}

Keywords: contextualization; meta-analysis; effect size; science achievement; Philippines 


\section{Introduction}

The prime aim of science education is to develop functionally scientifically literate learners (Härtig et al., 2020; Karisan \& Zeidler, 2016; Programme for International Student Assessment [PISA], 2015), who can become responsible members of society. A person is scientifically literate when they can make informed decisions about everyday life situations and issues that involve science content, and can read, understand, and critically reflect on information from various sources on the impact of science and technology on society (PISA, 2015). Considering the unprecedented environmental, scientific, and health challenges facing the world today, and in response to science education reforms that are focused on essential science content rather than coverage (Karisan \& Zeidler, 2016), the need to develop useful science, technology, engineering, and mathematics (STEM) knowledge in individuals through contextualization is imperative (Fortus \& Krajcik, 2020). Giamellaro (2017) describes context-based science education as teaching science based on the local environment and grounded on what students experience. It is relatively easy to expand students' knowledge with locally available materials, because familiarity with these resources renders science interesting and useful to learners' lives, and the nation. Educators, teachers, and policymakers have embraced contextualization as a constructivist approach and an inquiry-based teaching practice that bridges the gap between concepts and real-life experiences (Rivet \& Krajcik, 2008). Decades of research in science education has generated ample evidence that contextualization facilitates students' perceptions and improves their interest in science content (Giamellaro, 2014; King \& Ritchie, 2012). However, according to Fortus and Krajcik (2020), there is a caveat, that contextualized learning environments must be designed appropriately to avoid inappropriate contextualization, which can create confusion and activate irrelevant knowledge. Rivet and Krajcik (2008) characterize contextualization as a pedagogical approach that uses students' background knowledge and familiar experiences to help them grasp science ideas and concepts. Various terms are associated with contextualized instruction, such as an integrated approach (Pearson et al., 2010), contextualized instruction (Baker et al., 2009), embedded teaching and learning (Argelagos \& Pifarre, 2012), functional context education (Sticht, 2005), and indigenized knowledge (Owuor, 2007).

Much focus is on implementing contextualization in the classroom setting. Several studies attribute the positive effect of the approach to the teaching and learning process. The contextualized aspects of science instruction promote students' understanding of empirical evidence (Buck et al., 2014) and enhance science process skills, particularly observation skills (Clough, 2011). The effectiveness of contextualized instruction has been examined in the fields of physics (Rivet \& Krajcik, 2008), chemistry (Reigosa \& Jiménez-Aleixandre, 2007), and biology, specifically, genetics (Eklund et al., 2007). The latter investigated the relationship between genes and proteins using a problem-based approach. In terms of implementation, contextualization in the literature covers a range of settings, from text-based situations to immersive experiences in real-world settings (Giamellaro, 2017). Most of these studies reveal a variety of features and strategies of contextualization, depending on the context, learners, discipline, and other factors. Like other strategies, contextualization also has its limitations. For 
instance, Lin (2018) observes that, although a highly contextualized group of learners performed better in science, creating highly contextualized media required more teacher preparation time. Curry and Kirwan (2014) report no significant differences in mastery of agricultural biotechnology by students taught using agriculture-context versus scientific-basis approaches. This finding may be due to what Giamellaro (2014) explains: "framing a concept within a hypothetical context that the learner is not familiar with only adds another layer of abstraction rather than truly contextualizing the concept."

While empirical studies have examined the effect of contextualization in various disciplines, few systematic reviews have assessed the effectiveness of this approach in relation to achieving learning outcomes. Perin (2011) evaluated the evidence reported on using contextualization for teaching reading, writing, or arithmetic. Despite methodological constraints, the studies report that contextualization can accelerate the progress of academically underprepared college students. Karisan and Zeidler (2017) reviewed empirical studies centered on the contextualization of the nature of science in the socioscientific issue-based (SSI) framework. Their review provides evidence that the interaction between students' views on, their understanding of, and their response to the nature of science is contingent on the socioscientific issue-based context presented to them. Considering Giamellaro's (2017) study, primary contextualization could promote conceptual understanding; however, it is premature to conclude that contextualization is superior to approaches that do not use contextualization. Several factors must be considered, such as students' developmental level, differences in the content, and student characteristics. It is in this context that this study is grounded. As far as the authors could ascertain, there was, at the time of writing, no other systematic review paper that critically examines individual studies on the use of contextualization in teaching science.

\subsection{Contextualization in the Context of the Study}

It is worth taking a closer look at the implementation of contextualization in Philippine science education, for three reasons. First, the science items in the questionnaires of large-scale international standards, such as Trends in Mathematics and Science Study (TIMSS) and PISA, require a high level of contextualization. Second, Nentwig et al. (2009) recommend that these measures ensure the development of scientific literacy and that items draw out the ability of students to extract relevant information from various sources and use it to deal with science-related problems. Unfortunately, Filipino learners consistently perform dismally in standard national and international science assessments (Balagtas et al., 2019). Some of the factors identified as contributing to this poor performance include the instructional materials, the curriculum, and the teachinglearning process in general (Department of Science and Technology Science Education Institute \& University of the Philippines National Institute for Science and Mathematics Education Development, 2011). This poor performance by learners serves as an indicator of and a compelling reason for the shift to the $\mathrm{K}$ to 12 Program as enacted through Republic Act 10533 ("Enhanced Basic Education Act") last 2013, which has the ultimate goal of producing holistically developed and globally competitive Filipino learners. 
The second reason for the need to conduct this meta-analysis is the provision of the revised curriculum in the Philippines. One of the domains of science learning in curriculum design is understanding and applying scientific knowledge in the local and global setting, whenever possible. Success in this domain can be facilitated with various approaches, such as inquiry-based, contextual learning, problem-based, science technology-society, multidisciplinary, and interdisciplinary approaches (Department of Education, 2016). The $\mathrm{K}$ to 12 Education curriculum was cascaded across school settings, and involved teachers being upskilled and provided with pedagogical retooling and content enrichment opportunities that were geared to achieving effective, context-based teaching practices. Along with several other initiatives, effective program implementation can surely be manifested through the learning progress of students and the instructional effectiveness of teachers.

Finally, the aim of this current investigation is reporting on the curriculum, enacted vis-à-vis contextualized instruction, and described by empirical studies conducted by teachers and researchers in the Philippines. The extent of effectiveness of contextualization is gauged through analysis of studies undertaken in various scientific disciplines, such as biology (Belen \& Caballes, 2020; Tabotabo-Picardal \& Paño, 2017), chemistry (Sanchez, 2017, 2021), physics (Rivera \& Sanchez, 2020), environmental science (Tadena \& Salic-Hairulla, 2021), and home-based experimentation (Sanchez et al., 2021). The popularity of the contextualization approach as an instructional intervention warrants further investigation into the extent of its effectiveness in helping students achieve learning outcomes, as do the various strategies employed in contextualization instruction. This review aimed to identify features of contextualized instruction that are likely to lead to success. The researchers used a meta-analysis to survey recently published contextualization studies in the Philippines, and to assess the relative effect sizes of different kinds and conditions of this instructional approach.

\subsection{Purpose of the Study}

The meta-analysis examined the overall effect of contextualization strategies, as integrated and implemented in science education, on student learning achievement. More specifically, this meta-analysis (1) Determined the effectiveness of contextualized instruction in science for maximizing student learning; (2) Compared the effect sizes of the studies analyzed, in terms of year, locale, design, educational level, and domain; and (3) Identified contextualization strategies that have been employed in science instruction.

\section{Methods}

\subsection{Research Design}

This study used the meta-analysis design, which is a form of systematic literature review, to determine whether contextualization in science teaching is effective in increasing student achievement. By following the step-by-step guide by Tawfik et al. (2019), the researchers collected empirically-based published studies, coded characteristics of these studies, and calculated the effect sizes using a common 
scale. Finally, they investigated the moderating effects of the studies on the outcome measure.

\subsection{Search and Selection Criteria}

A systematic search was done for research published from 2017 to 2020 that assessed the effectiveness of the contextualization approach on student learning; this was done by obtaining and examining sources after undertaking a PRISMA flow. PRISMA flow refers to the flow of information, through identification, screening, and eligibility (see Funa \& Prudente, 2021). The PRISMA flow of the present meta-analysis is illustrated in Figure 1.

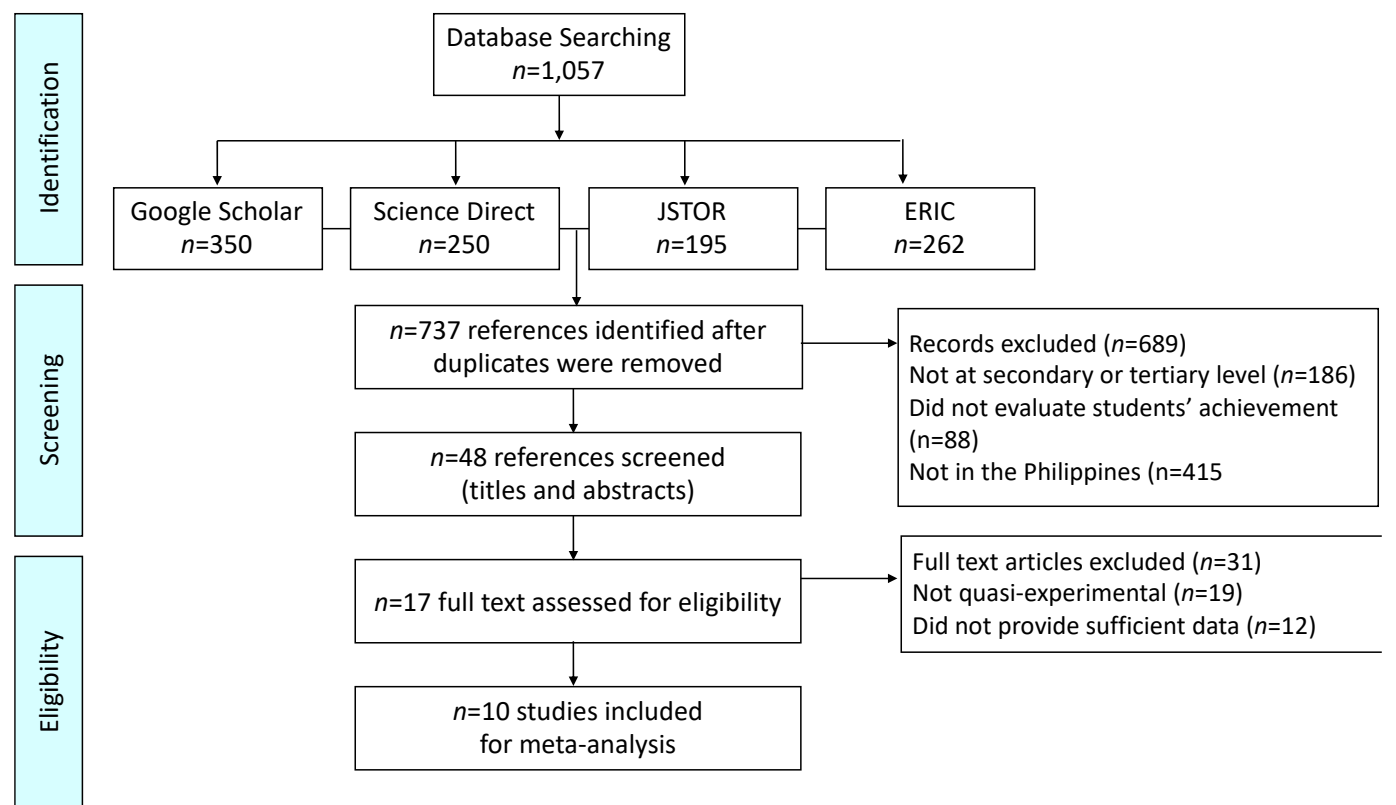

Figure 1. PRISMA flow diagram for selecting studies for the meta-analysis

Firstly, the studies were identified by examining search results for databases such as Google Scholar, Science Direct, JSTOR, and ERIC, using relevant keywords, such as "science," "contextualization," "Philippines." These words were used randomly and interchangeably in the search engines. Words such as "contextualization," "contextualized teaching," or "context-based teaching" were used repeatedly until all studies had been found. An initial search, which used Publish or Perish software (Harzing, 2007), found 1,057 studies.

The researchers established several criteria for inclusion in the systematic review. First, the meta-analysis included research studies that had primarily used a quasiexperimental design and which had been published in refereed journals during a period of three years (2017-2020). Second, to be included, the studies had to satisfy the following criteria: (a) They had to have focused on contextualized instruction in Philippine K to 12 classrooms, where students and teachers interacted primarily through face-to-face interaction; (b) Studies had to compare a traditional set-up of instruction and contextualized instruction groups; (c) Studies had to compare pretest and posttest measures of the groups, and (d) Studies had to report 
statistical data, such as means, standard deviations, $t$-values or $F$-values, which enabled the meta-analysis to compute effect sizes.

Certain types of studies were excluded from the meta-analysis. Many studies were excluded because they did not report the appropriate statistical data we needed to compute the effect sizes. For instance, some studies only reported certain raw scores for a few students in the experimental group, and did not include the overall scores for experimental and control groups. The search and selection process identified 10 studies that were Philippine-based. These 10 studies are preceded by an asterisk in the reference list.

\subsection{Data Analysis}

To place or calibrate the results of the studies that met the criteria on a common scale, effect sizes were computed and measured using Hedge's $g$ values. This calculation involved dividing the difference between experimental and control groups means by the standard deviation of the control group (Lakens, 2013). Hedge's $g$ was preferred over Cohen's $d$, as the former is better at adjusting for small sample size bias than the latter (Borenstein et al., 2010). Thus, effect sizes can be regarded as standardized measures of where the experimental data stand in the control data distribution. In this meta-analysis, a positive effect size means that the group that had been exposed to contextualized instruction received more desirable and higher scores than the control group, which had been exposed to a traditional setup. The magnitude of the effect size is based on the criteria of Cohen (1988), which specify that $g$ values of 0.80 and above are considered to have large effects; vales of $0.50-0.79$ have medium effect; and below 0.50 , no effect.

Statistical analyses were performed using the meta-essentials workbook, version 1.4, licensed under the Creative Commons Attribution-NonCommercialShareAlike 4.0 International License developed by Suurmond et al. (2017) and interpreted using the user manual provided by Van Rhee et al. (2015). Conditional subgroup and moderator analyses were done when heterogeneity $\left(\mathrm{I}^{2}\right)$ was high (Borenstein et al., 2009), which provided the researchers the opportunity to investigate further the role of various variables in the effect size of contextualization in science learning. These variables were the year, locale, research design, educational level, and science domain. Publication bias was visualized using the funnel plot and quantitatively described using the BeggMazumdar test, which was preferred over Egger regression, due to its consideration of smaller samples (Begg \& Mazumdar, 1994; Harbord et al., 2009). All tests were performed at a 95\% confidence level (CI), and all p-values lower than .05 were considered significant.

\section{Results and Discussion}

\subsection{General Study Characteristics}

A sample size of 713 secondary and tertiary-level students from quantitative studies in the Philippines constituted the meta-analysis. Table 1 describes these quantitative studies in terms of year of publication, study locale, research design, sample size, grade level, and science domain. 
Table 1: General characteristics of 10 studies that investigated contextualized science instruction

\begin{tabular}{|c|c|c|c|c|c|c|c|}
\hline \multirow{2}{*}{ Authors } & \multirow{2}{*}{ Year } & \multirow{2}{*}{ Locale } & \multirow{2}{*}{ Design } & \multicolumn{2}{|c|}{ Sample Size } & \multirow{2}{*}{$\begin{array}{l}\text { Educ. } \\
\text { Level }\end{array}$} & \multirow{2}{*}{ Domain } \\
\hline & & & & Cont. & Exp. & & \\
\hline Ole & 2020 & $\begin{array}{l}\text { Western } \\
\text { Visayas }\end{array}$ & Quasi & 21 & 21 & College & Physics \\
\hline $\begin{array}{l}\text { Rivera \& } \\
\text { Sanchez }\end{array}$ & 2020 & $\begin{array}{l}\text { Central } \\
\text { Visayas }\end{array}$ & Quasi & 46 & 46 & G10 & Chemistry \\
\hline Borre & 2019 & Bicol & Quasi & 30 & 37 & G8 & Biology \\
\hline $\begin{array}{l}\text { Enteria \& } \\
\text { Casumpang }\end{array}$ & 2019 & Caraga & Mixed & 30 & 30 & HS & Biology \\
\hline Dioneda & 2019 & Calabarzon & Quasi & 40 & 40 & G7 & Biology \\
\hline Magwilang & 2019 & Cordillera & Mixed & 48 & 48 & College & Chemistry \\
\hline $\begin{array}{l}\text { Valdez \& } \\
\text { Bungihan }\end{array}$ & 2019 & $\begin{array}{l}\text { Cagayan } \\
\text { Valley }\end{array}$ & Quasi & 50 & 46 & G9 & Chemistry \\
\hline $\begin{array}{l}\text { Obiedo \& } \\
\text { Jugar }\end{array}$ & 2017 & $\begin{array}{c}\text { Central } \\
\text { Visayas } \\
\end{array}$ & Quasi & 45 & 45 & College & Physics \\
\hline Sagcal et al. & 2017 & $\begin{array}{c}\text { National } \\
\text { Capital }\end{array}$ & Mixed & 30 & 30 & G10 & Chemistry \\
\hline Sanchez & 2017 & $\begin{array}{l}\text { Central } \\
\text { Visayas }\end{array}$ & Quasi & 15 & 15 & G10 & Chemistry \\
\hline
\end{tabular}

Ten studies were included in this meta-analysis. Of these studies, three studies were published in 2017, five in 2019, and two in 2020. The studies were conducted in different areas of the country: five in Luzon, four in the Visayas, and one in Mindanao. Moreover, all studies were conducted as quasi-experiments; however, three papers were combined with other quantitative or qualitative designs. Sample sizes of the participating groups in the studies range from 15 to 50. Furthermore, the studies involved different grade levels and science domains: three studies were implemented in a biology class, five in chemistry, and two in physics. These empirical studies were undertaken after the country's shift to the K to 12 basic education system as announced in the Republic Act 10533 in 2013, according to which science teaching had to be facilitated by problem or issuebased learning and contextualized learning approaches (Department of Education, 2016).

\subsection{Effect Sizes of Contextualized Instruction in Science}

The effect sizes of studies that investigated contextualized instruction are presented in Table 2. 
Table 2: Effect sizes and forest plot of studies that investigated contextualized instruction in science

\begin{tabular}{|c|c|c|c|c|c|c|c|c|}
\hline \multirow{2}{*}{$\begin{array}{l}\text { Authors } \\
\text { (first author) }\end{array}$} & \multirow{2}{*}{ Hedge's $g$} & \multicolumn{2}{|c|}{$95 \%$ CI } & \multicolumn{5}{|c|}{ Forest Plot } \\
\hline & & Lower & Upper & 0 & 2 & 4 & 6 & 8 \\
\hline Ole & 1.56 & 0.89 & 2.3 & & & & & \\
\hline Rivera & 0.9 & 0.47 & 1.34 & & & & & \\
\hline Borre & 1.72 & 1.17 & 2.31 & & & & & \\
\hline Enteria & 1.17 & 0.63 & 1.73 & & & & & \\
\hline Dioneda & 3.94 & 4.74 & 3.22 & & & & & \\
\hline Magwilang & 1.85 & 1.38 & 2.35 & & & & & \\
\hline Valdez & 0.51 & 0.11 & 0.92 & & & & & \\
\hline Obiedo & 0.83 & 0.41 & 1.27 & & & & & \\
\hline Sagcal & 2.89 & 2.2 & 3.66 & & & & & \\
\hline Sanchez & 1.04 & 0.29 & 1.85 & & & & & \\
\hline $\begin{array}{l}\text { Combined } \\
\text { effect }\end{array}$ & 1.61 & 0.87 & 2.35 & & & & & \\
\hline
\end{tabular}

According to Table 2, all the individual Hedge's $g$ values are within the 95\% CI, and are located entirely on the positive side of zero. It means that significant improvements in students' science learning occurred in the context of the studies. However, these studies have different effect sizes and have different degrees of effectiveness. For example, the study of Valdez and Bungihan (2019) has the lowest effect size $(g=0.51)$, which signifies a medium effect; students exposed to problem-based learning enhanced their problem-solving skills in chemistry more than the average. In turn, the study of Dioneda (2019) has the largest effect size, at $g=3.94$, which means that a student exposed to localized and contextualized teaching improved their biology performance to a greater extent than the control group. These quantitative studies are supported by the other Philippine studies on using contextualization in science (Belen \& Caballes, 2020; Sanchez et al., 2021; Tabotabo-Picardal \& Picardal, 2017; Tadena \& Hairulla, 2021), which indicates that the instructional approach investigated by the meta-analysis has a positive effect on science learning.

The combined effect size is 1.61, which is within the 95\% CI and on the positive side of zero. However, the Z- and p-values derived from the analysis show a significant difference among the studies included in this meta-analysis. This is also evident in the value of $\mathrm{I}^{2}(90.77 \%)$, which indicates a high heterogeneity among studies into contextualized science instruction. The effect of this type of instruction varies between studies - of which not all involved the same population distribution. Hence, subgroup and moderator analyses were also performed (Borenstein et al., 2009). 
3.3 Effect Sizes of Subgroups of Studies in Contextualized Science Instruction Because the I ${ }^{2}$ values are very high, subgroup analysis was conducted. Results of the subgroup analysis are reported in Table 3.

Table 3: Subgroup analysis of studies that investigated contextualized science instruction

\begin{tabular}{|c|c|c|c|c|c|c|c|}
\hline \multirow{2}{*}{ Category } & \multirow{2}{*}{ Subgroups } & \multirow{2}{*}{$\mathbf{n}$} & \multicolumn{3}{|c|}{ Test for Heterogeneity } & \multicolumn{2}{|c|}{ Test for Effect } \\
\hline & & & $\mathbf{I}^{2}$ & Q-stat & p-value & Hedge's $g$ & 95\% CI \\
\hline \multirow{3}{*}{ Year } & 2017 & 3 & $91.62 \%$ & 23.86 & .000 & 1.57 & $0.28,2.86$ \\
\hline & 2019 & 5 & $94.11 \%$ & 67.87 & .000 & 1.81 & $0.69,2.92$ \\
\hline & 2020 & 2 & $62.18 \%$ & 2.64 & .104 & 1.17 & $0.53,1.82$ \\
\hline \multirow{3}{*}{ Locale } & Luzon & 5 & $94.91 \%$ & 78.59 & .000 & 2.15 & $1.02,3.29$ \\
\hline & Visayas & 4 & $12.62 \%$ & 3.43 & .330 & 1.00 & $0.71,1.28$ \\
\hline & Mindanao & 1 & $0.00 \%$ & 0.00 & - & 1.17 & - \\
\hline \multirow{2}{*}{ Design } & Pure quasi-exp. & 7 & $91.65 \%$ & 71.85 & .000 & 1.47 & $0.62,2.31$ \\
\hline & Mixed & 3 & $85.87 \%$ & 14.15 & .001 & 1.94 & $0.97,2.91$ \\
\hline \multirow{2}{*}{ Educ. Level } & Secondary & 7 & $93.13 \%$ & 87.33 & .000 & 1.71 & $0.80,2.62$ \\
\hline & Tertiary & 3 & $69.07 \%$ & 10.20 & .006 & 1.40 & $0.79,2.01$ \\
\hline \multirow{3}{*}{ Domain } & Biology & 3 & $94.41 \%$ & 35.81 & .000 & 2.25 & $0.59,3.91$ \\
\hline & Chemistry & 5 & $90.42 \%$ & 41.74 & .000 & 1.41 & $0.59,2.23$ \\
\hline & Physics & 2 & $68.35 \%$ & 3.16 & .075 & 1.15 & $0.43,1.86$ \\
\hline
\end{tabular}

As shown in Table 3, the $\mathrm{I}^{2}$ values of most subgroups are greater than $90 \%$, indicating a significant difference between the studies that were included in the meta-analysis. There is high heterogeneity among the studies in a subgroup, which may mean that the studies were conducted in different population contexts. However, some subgroups have $I^{2}$ values less than $75 \%$. These subgroups (2020, Visayas, tertiary, and physics) are considered to be moderately heterogeneous, with some degree of homogeneity. Studies in 2020, Visayas, at tertiary level, and in physics have this characteristic. However, only 2020, Visayas, and physics studies do not have significant differences in the population contexts $(p=.104, .330$, .075 , respectively). This finding shows that these subgroups include studies of the same population.

Contextualized science instruction is associated with better student performance across publication years, locales, research designs, educational levels, and science domains, as shown by large effect sizes $(g>0.50)$ and positive locations in the forest plot. This means that the impact of contextualized teaching is evident in students' science learning. This result is coherent with a meta-analysis study by Schroeder et al. (2007), which found that enhanced contextualized strategies for teaching science had, of all the strategies studied, the greatest effect on science learning. 
Furthermore, the present study reports that contextualization affects all subgroups, which can be attributed to the many facets of contextualization in teaching science, including academic, secondary, primary, and overcontextualization strategies (Giamellaro, 2017).

\subsection{Effect Sizes of Moderators}

The results of the moderator analysis are presented in Table 4.

Table 4: Moderator analysis of studies that investigated contextualized science instruction

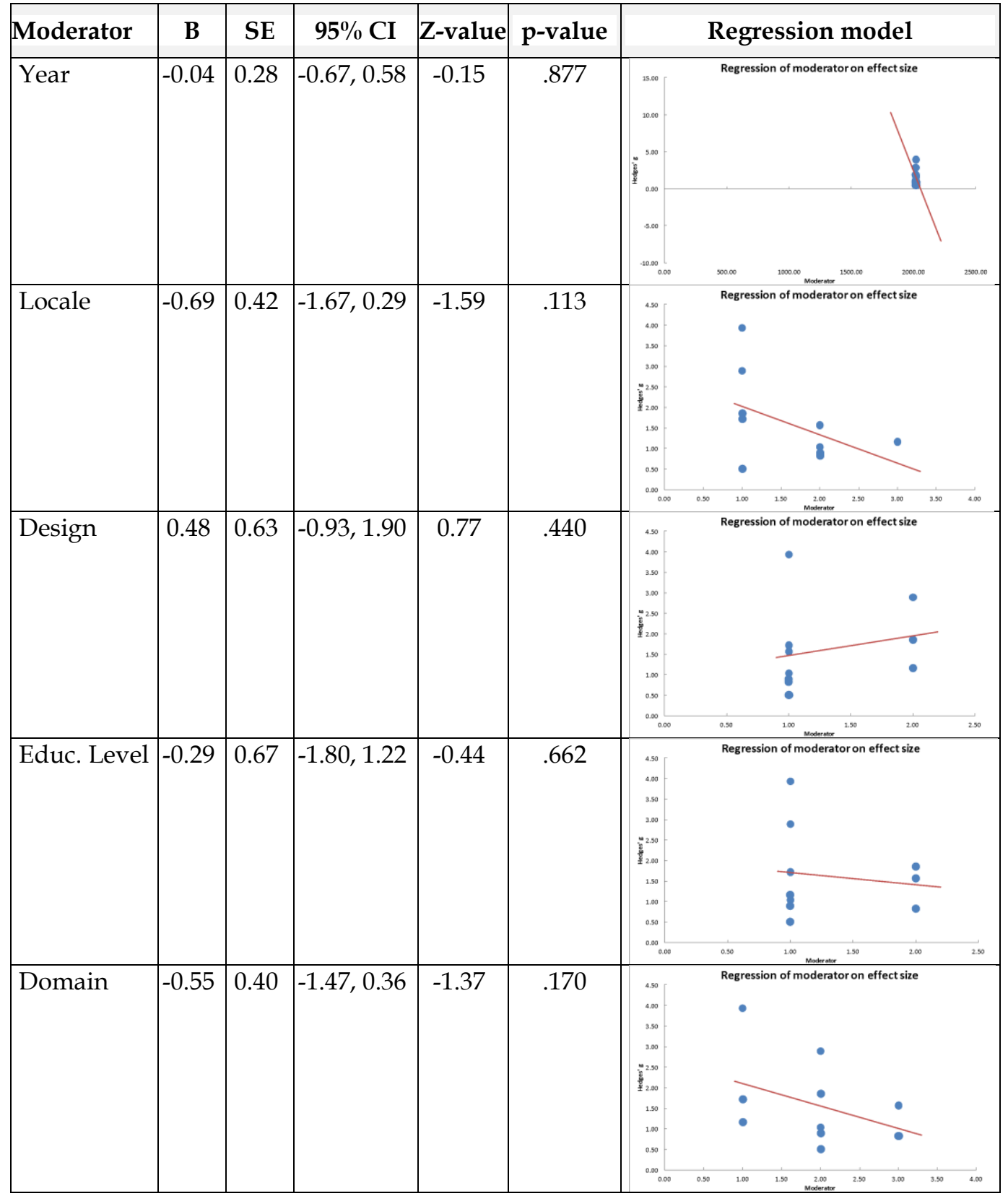

Regression plots and lines can be interpreted through the steepness of the line. The publication year illustrates a very steep downward line that can be interpreted as indicating that a drastic change in effect size will be observed if 
studies are published the next year. However, data analysis found that the publication year does not influence effect size $(p=.877)$. Lines of locale and science domain are neither steep nor flat. Therefore, these variables are probable candidates for influencing effect size. However, just like the publication year, locale and science domain do not significantly affect the effect size $(p=.113, .170$, respectively). Other moderators have regression lines that are not steep, but are almost flat. It means that a change in the moderator does not affect the effect size. This result is supported by high $p$-values for design $(p=.440)$ and educational level $(p=.662)$. Hence, publications about contextualization in science education are not influenced by the moderators mentioned above, because better learning was observed across different subgroups. Contextualization can be applied to any context group, thereby making the learning approach flexible and innovative (Giamellaro, 2017; Suryawati \& Osman, 2018).

\subsection{Publication Bias}

The funnel plot is presented in Figure 2.

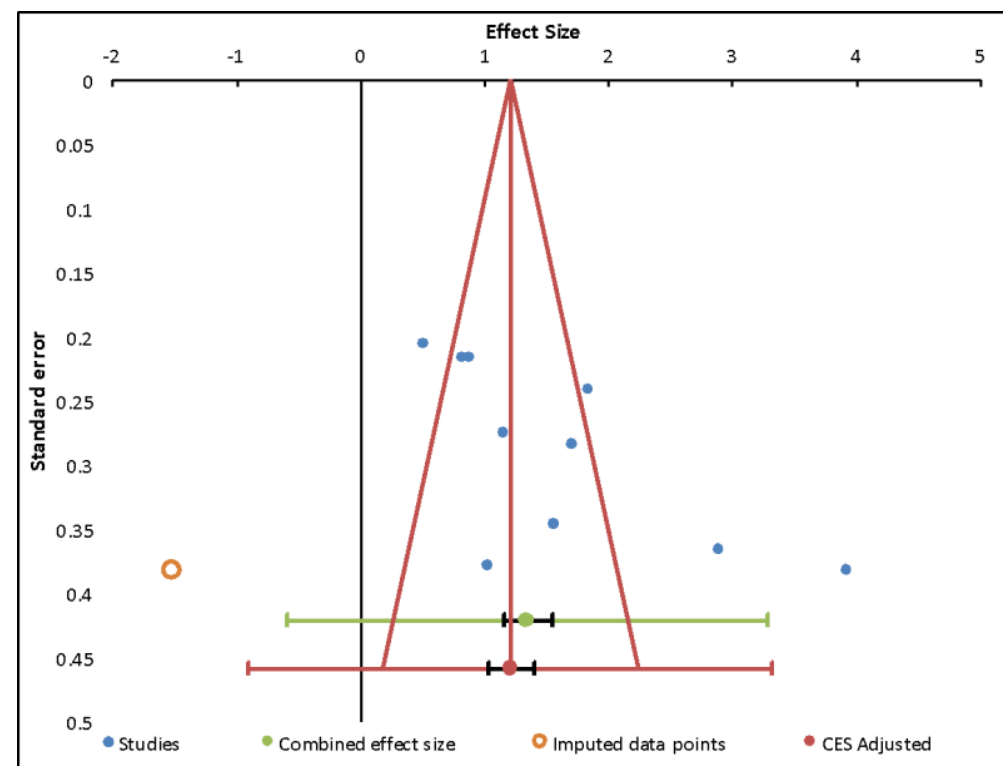

Figure 2: Funnel plot of standard error, indicating publication bias

Consideration of the funnel plot indicates the probability of publication bias. Unequal distributions around average effect sizes create an asymmetrical funnel. To confirm this finding, Begg-Mazumdar rank correlation and fail-safe $\mathrm{N}$ tests were conducted. The Begg-Mazumdar rank correlation yielded Kendall's tau of $0.56(p=0.025)$. The classical fail-safe $\mathrm{N}$ test results indicates that 1,058 additional studies about contextualized science instruction are needed to nullify the overall effect size revealed by the present meta-analysis. Finally, Orwin's fail-safe $N$ test results state that 834 missing null studies are needed to bring the current overall average size to a particular level. Although the fail-safe test results are good, the visual inspection and Kendall's tau show manifestations of publication bias. This finding means that authors of contextualized science instruction studies tend to publish studies that impact learning positively, and exclude insignificant results from their publications. 


\subsection{Strategies in Contextualized Science Instruction}

Contextualized science instruction is an approach to teaching (Suryawati \& Osman, 2018). Therefore, there are many methods or strategies for implementation in the class. Table 5 tabulates these strategies in the context of the studies included in this meta-analysis.

Table 5: Strategies in contextualized science instruction

\begin{tabular}{|l|c|c|l|}
\hline Strategy & Frequency & Percentage & \multicolumn{1}{|c|}{ Study Exemplar } \\
\hline $\begin{array}{l}\text { Use of local/ } \\
\text { community knowledge }\end{array}$ & 10 & $100 \%$ & $\begin{array}{l}\text { Borre (2019) incorporated local and } \\
\text { familiar events and taught biology } \\
\text { using anecdotes. }\end{array}$ \\
\hline Instructional materials & 6 & $60 \%$ & $\begin{array}{l}\text { Enteria and Casumpang (2019) } \\
\text { developed comic strips that } \\
\text { showcase contextualized situations } \\
\text { that can help solve environmental } \\
\text { problems in the locality. }\end{array}$ \\
\hline Problem-solving & 3 & $30 \%$ & $\begin{array}{l}\text { Obiedo and Jugar (2017) } \\
\text { contextualized problem-solving to } \\
\text { maritime contexts. }\end{array}$ \\
\hline Laboratory activities & 3 & $30 \%$ & $\begin{array}{l}\text { Sagcal et al. (2017) implemented lab } \\
\text { activities relevant to daily life and } \\
\text { used materials commonly and } \\
\text { readily available in the community. }\end{array}$ \\
\hline $\begin{array}{l}\text { Combination with } \\
\text { other strategies }\end{array}$ & 2 & $20 \%$ & $\begin{array}{l}\text { Sanchez (2017) embedded } \\
\text { contextualization in lab, iconic, and } \\
\text { problem-solving activities. }\end{array}$ \\
\hline
\end{tabular}

As explained in Table 5, all the studies incorporated local or community knowledge - see the study of Borre (2019). Some contexts are relevant to the students' learning environment - that is the reason the study of Obiedo and Jugar (2017) used maritime contexts in their problem-solving activities. Most of the contexts are incorporated in science teaching through the creation of instructional materials, such as comic strips (Enteria \& Casumpang, 2019), low-cost materials (Rivera \& Sanchez, 2020; Sagcal et al., 2017), and modules (Ole, 2020).

The use of contextualized teaching in problem-solving is the third-most used strategy in the included studies. Obiedo and Jugar (2017) exemplified an integrated maritime context for teaching physics. Contextualization is also evident in laboratory activities. Sagcal et al. (2017) developed certain criteria to construct context-based lab activities; these criteria are parallel to the aims of $\mathrm{K}$ to 12 , are relevant to students' daily lives, use low-cost or readily available materials, and improvise certain materials. Sanchez (2017) implemented lab experiments that reflect phenomena in students' everyday lives.

Lastly, contextualization was found to be used with other strategies. For example, Borre (2019) implemented contextualization of biology instruction and flipped classroom delivery, skills development, and visual material utilization, while 
Sanchez (2017) integrated contextualized activities in macroscopic, symbolic, and microscopic modes for teaching chemistry.

\section{Conclusion and Future Directions}

Contextualized instruction has contributed to improving science learning. All the studies in the meta-analysis have high effect sizes and are located on the positive side of the forest plot. Publication year, study locale, research design, educational level, and science domain can be related to improved science performance, but do not significantly influence such learning in the future. Contextualization can be implemented across context groups and can improve students' learning and performance. Providing contextualization, localization, and indigenization in the country's $\mathrm{K}$ to 12 basic education system is crucial for immersing students in meaningful experiences that lead to better learning in science.

The studies in the meta-analysis have high heterogeneity, indicating that the studies were done in different population contexts and were implemented in various ways; hence, it is recommended that papers from other geographical contexts are included to gain insights of how contextualization affects learning in their contexts. A further systematic review should be conducted, and should cover a larger scope, to examine various indicators that may influence the implementation of contextualization in the teaching and learning process. Furthermore, heterogeneity and significant Begg-Mazumdar rank correlation results show publication bias; therefore, we suggest that researchers also report insignificant statistical results in published studies, to provide information on the overall impact of contextualization in science teaching.

\section{Acknowledgments}

The researchers extend their gratitude to the Institute for Research in Innovative Instructional Delivery (IRIID) of Cebu University, for the funding that paved the way for the execution and completion of this research project. They also thank the Research Institute for Tropical Biology and Pharmacological Biotechnology (RITBPB), whose collaboration with IRIID provided the necessary capability training that led to the conceptualization of this paper.

\section{References}

Argelagos, E., \& Pifarré, M. (2012). Improving information problem-solving skills in secondary education through embedded instruction. Computers in Human Behavior, 28(2), 515-526. https:/ / psycnet.apa.org/doi/10.1016/j.chb.2011.10.024

Balagtas, M. U., Garcia, D. C. B., \& Ngo, D. C. (2019). Looking through Philippine's K to 12 Curriculum in Mathematics and Science vis-a-vis TIMSS 2015 Assessment Framework. EURASIA Journal of Mathematics, Science and Technology Education, 15(12), em1788. https://doi.org/10.29333/ejmste/108494

Baker, E. D., Hope, L., \& Karandjeff, K. (2009). Contextualized teaching and learning: A faculty primer. A review of literature and faculty practices with implications for California community college practitioners. The Research and Planning Group for California Community Colleges, Center for Student Success.

Begg, C. B., \& Mazumdar, M. (1994). Operating characteristics of a rank correlation for publication bias. Biometrics, 50(4), 1088-1101. 
Belen, J. L., \& Caballes, G. D. (2020). Contextualization of activities in selected topics in molecular biology. Biometrics and Bioinformatics, 12(1), 6-10.

Borenstein, M., Hedges, L., Higgins, J. P., \& Rothstein, H. R. (2009). Introduction to metaanalysis. Wiley \& Sons.

Borenstein, M., Hedges, L., Higgins, J. P., \& Rothstein, H. R. (2010). A basic introduction to fixed-effect and random-effects models for meta-analysis. Research Synthesis Methods, 1(2), 97-11. https:/ / doi.org/10.1002/jrsm.12

Borre, J. C. (2019). Teaching biology using contextualized learning kit. The Proceedings of the Asian Conference on Education \& International Development 2019. http:/ /25qt511nswfi49iayd31ch80-wpengine.netdna-ssl.com/wpcontent/uploads/papers/aceid2019/ACEID2019_45818.pdf

Buck, G. A., Akerson, V. L., Quigley, C. F., \& Weiland, I. S. (2014). Exploring the potential of using explicit reflective instruction through contextualized and decontextualized approaches to teach first-grade African American girls the practices of science. Electronic Journal of Science Education, 18(6), 1-21. http://ejse.southwestern.edu/

Clough, M. (2011). Teaching and assessing the nature of science. The Science Teacher, 78(6), $56-60$.

Cohen, J. (1988). Statistical power analysis for the behavioral sciences (2nd ed.). Lawrence Erlbaum.

Curry, N., \& Kirwan, J. (2014). The role of tacit knowledge in developing networks for sustainable agriculture. Sociologia Ruralis, 54(3), 341-361. https://doi.org/10.1111/soru.12048

Department of Education (2016). K to 12 curriculum guide. Science. Grade 3 to Grade 10. Republic of the Philippines Department of Education. https://www.deped.gov.ph/wp-content/uploads/2019/01/Science-CG_withtagged-sci-equipment_revised.pdf

Department of Science and Technology Science Education Institute, \& University of the Philippines National Institute of Science and Mathematics Education (2011). Science framework for Philippine basic education. SEI-DOST \& UP NISMED

Dioneda, I. P. (2019). Localization and contextualization in teaching Biology for grade 7 students of Paliparan National High School for school year 2018-2019. Ioer International Multidisciplinary Research Journal, 1(3), 19-27. https://www.ioerimrj.com/wp-content/uploads/2019/09/Localization-and-Contextualizationin-Teaching-Biology-for-Grade-7-Student-of-Paliparan-National-High-SchoolIsagani-P.-Dioneda-Jr..pdf

Eklund, J., Rogat, A., Alozie, N., \& Krajcik, J. (2007, April). Promoting student scientific literacy of molecular genetics and genomics. Annual Meeting of the National Association for Research in Science Teaching, New Orleans, LA. http://websites.umich.edu/ hiceweb/presentations/documents/Genetics_NA RST_07.pdf

Enteria, O. C., \& Casumpang, P. F. H. (2019). Effectiveness of developed comic strips as instructional material in teaching specific science concepts. International Journal for Innovation Education and Research, 7(10), 876-882. https://doi.org/10.31686/ijier.Vol7.Iss10.1835

Fortus, D., \& Krajcik, J. (2020). Supporting contextualization: Lessons learned from throughout the globe. In I. S. Tapia (Ed.), International perspectives on the contextualization of science education. Springer. https:// doi.org/10.1007/978-3030-27982-0_9 
Funa, A. A., \& Prudente, M. S. (2021). Effectiveness of problem-based learning on secondary students' achievement in science: A meta-analysis. International Journal of Instruction, 14(4), 69-84. https:// doi.org/10.29333/iji.2021.1445a

Giamellaro, M. (2014): Primary contextualization of science learning through immersion in content-rich settings. International Journal of Science Education, 36(17), 2848-2871. https:// doi.org/10.1080/09500693.2014.937787

Giamellaro, M. (2017). Dewey's yardstick: Contextualization as a crosscutting measure of experience in education and learning. SAGE Open, 7(1). https://doi.org/10.1177/2158244017700463

Harbord, R. M., Harris, R. J., \& Sterne, J. A. (2009). Updated tests for small-study effects in meta-analysis. The Strata Journal, 9(2), 197-210. https://doi.org/10.1177\%2F1536867X0900900202

Härtig, H., Nordine, J. C., \& Neumann, K. (2020). Contextualization in the assessment of students' learning about science. In I. S. Tapia (Ed.), International perspectives on the contextualization of science education. Springer. https:// doi.org/10.1007/978-3030-27982-0_6

Harzing, A.-W. (2007). Publish or perish. Harzing.com. https://harzing.com/resources/publish-or-perish

Karisan, D., \& Zeidler, D. L. (2017). Contextualization of nature of science within the socioscientific issues framework: A review of research. International Journal of Education in Mathematics, Science and Technology, 5(2), 139-152. https://doi.org/10.18404/ijemst.270186

King, D., \& Ritchie, S. M. (2012). Learning science through real-world contexts. In B. Fraser, K. Tobin, \& C. McRobbie (Eds.), Second International Handbook of Science Education (Springer International Handbooks of Education, Vol. 24). Springer. https://doi.org/10.1007/978-1-4020-9041-7_6

Lakens, D. (2013). Calculating and reporting effect sizes to facilitate cumulative science: A practical primer for $t$-tests and ANOVAs. Frontiers in Psychology, 4. https://doi.org/10.3389/fpsyg.2013.00863

Lin, Y. R. (2018). The influences of contextualized media on students' science attitudes, knowledge, and argumentation learning through online game-based activities. Journal of Computer Assisted Learning, 34(6), 884-898. https://doi.org/10.1111/jcal.12297

Magwilang, E. B. (2019). Development and validation of a community-based learning resource package in inorganic chemistry. International Journal of Humanities and Social Sciences, 11(2), 33-41. https://doi.org/10.26803/ijhss.11.2.3

Nentwig, P., Roennebeck, S., Schoeps, K., Rumann, S., \& Carstensen, C. (2009). Performance and levels of contextualization in a selection of OECD countries in PISA 2006. Journal of Research in Science Teaching, 46(8), 897-908. https://doi.org/10.1002/tea.20338

Obiedo, R. V., \& Jugar, R. R. (2017). Contextualized teaching on the problem solving performance of students. University of Mindanao International Multidisciplinary Research Journal, 2(1), 1-8. http://journal.umindanao.edu.ph/wpcontent/uploads/2018/01/UM20172110_Contextualized-teaching-on-theproblem-solving-.pdf

Ole, F. C. B. (2020). Effect of a developed physics laboratory manual on the conceptual understanding of industrial technology students. European Journal of Education Studies, 7(6), 113-123. https:/ / doi.org/10.5281/zenodo.3890894

Owuor, J. (2007). Integrating African indigenous knowledge in Kenya's formal education system: The potential for sustainable development. Journal of Contemporary Issues in Education, 2(2), 21-37. https://doi.org/10.20355/C5Z594 
Perin, D. (2011). Facilitating student learning through contextualization: A review of evidence. Community College Review, 39(3), 268-295. https://doi.org/10.1177\%2F0091552111416227

Pearson, P. D., Moje, E., \& Greenleaf, C. (2010). Literacy and science: Each in the service of the other. Science, 328(5977), 459-463. https:// doi.org/10.1126/science.1182595

Programme for International Student Assessment (2015). Draft science framework. PISA. https://www.oecd.org/pisa/pisaproducts/Draft\%20PISA\%202015\%20Science $\% 20$ Fram ework $\% 20$.pdf

Reigosa, C., \& Jiménez-Aleixandre, M. P. (2007). Meaning construction and contextualization while solving a dynamics task in the laboratory. In R. Pintó, \& D. Couso (Eds.), Contributions from science education research. Springer. https://doi.org/10.1007/978-1-4020-5032-9_13

Rivera, G. M., \& Sanchez, J. M. P. (2020). Use of contextualized instructional materials: The case of teaching gas laws in a public uptown high school. Orbital: The Electronic Journal of Chemistry, 276--281. http://dx.doi.org/10.17807/orbital.v12i4.1526

Rivet, A. E., \& Krajcik, J. S. (2008). Contextualizing instruction: Leveraging students' prior knowledge and experiences to foster understanding of middle school science. Journal of Research in Science Teaching, 45(1), 79-100. https://doi.org/10.1002/tea.20203

Sagcal, R. R., Valera, N. S., \& Maquiling, J. T. (2017). Development and evaluation of context-based laboratory activities in chemistry using low-cost kits for junior public. Kimika, 28(2), 30-41. https:// doi.org/10.26534/kimika.v28i2.30-41

Sanchez, J. M. P. (2017). Integrated macro-micro-symbolic approach in teaching secondary chemistry. Kimika, 28(2), 22-29. https://doi.org/10.26534/kimika.v28i2.22-29

Sanchez, J. M. P. (2021). Understanding of kinetic molecular theory of gases in three modes of representation among tenth-grade students in chemistry. International Journal of Learning, Teaching and Educational Research, 20(1), 48-63. https:// doi.org/10.26803/ijlter.20.1.3

Sanchez, J. M. P., Fernandez, M. J. U., Abgao, J. M. O., Sarona, H. H., Asenjo, S. B. C., Guiroy, B. V., Oponda, A. J. D., \& Vale, X. M. (2021). Experimenting on natural acid-base indicators: A home-based chemistry activity during the COVID-19 pandemic as evaluated by teachers. Kimika, 32(1), 34-45. https:// doi.org/10.26534/kimika.v32i1.34-45

Schroeder, C. M., Scott, T. P., Tolson, H., Huang, T-Y., \& Lee, Y-H. (2007). A meta-analysis of national research: Effects of teaching strategies on student achievement in science in the United States. Journal of Research in Science Teaching, 44(10), 14361460. https://doi.org/10.1002/tea.20212

Sticht, T. (2005). Functional context education: Making learning relevant in the 21st century: Workshop participant's notebook. http://en.copian.ca/library/research/fce/fce.pdf

Suryawati, E., \& Osman, K. (2018). Contextualized learning: An innovative approach towards the development of students' scientific attitude and natural science performance. EURASIA Journal of Mathematics, Science and Technology Education, 14(1), 61-76. https://doi.org/10.12973/ejmste/79329

Suurmond, R., Van Rhee, H., \& Hak, T. (2017). Introduction, comparison and validation of Meta-Essentials: A free and simple tool for meta-analysis. Research Synthesis Methods, 8(4), 537-553. http://doi.org/10.1002/jrsm.1260

Tabotabo-Picardal, M., \& Paño, J. D. (2018). Facilitating instruction of central dogma of molecular biology through contextualization. Journal of Teacher Education and Research, 13(2), 118-132. http:// dx.doi.org/10.5958/2454-1664.2018.00012.5 
Tadena, M. T. G., \& Salic-Hairulla, M. A. (2021). Local-based lesson on hydrologic cycle with environmental education integration: Designing learners ideas through STEM. Journal of Physics: Conference Series, 1835(1), 012035. https://doi.org/10.1088/1742-6596/1835/1/012035

Tawfik, G. M., Dila, K. A. S., Mohamed, M. Y. F., Tam, D. N. H., Kien, N. D., Ahmed, A. M., \& Huy, N. T. (2019). A step by step guide for conducting a systematic review and meta-analysis with simulation data. Tropical Medicine and Health, 47(46). https:// doi.org/10.1186/s41182-019-0165-6

Valdez, J. E., \& Bungihan, M. E. (2019). Problem-based learning approach enhances the problem solving skills in chemistry of high school students. Journal of Technology and Science Education, 9(3), 282-294. https://doi.org/10.3926/jotse.631

Van Rhee, H. J., Suurmond, R., \& Hak, T. (2015). User manual for Meta-Essentials: Workbooks for meta-analysis (version 1.4). Erasmus Research Institute of Management. http://www.erim.eur.nl/research-support/meta-essentials 